\title{
Cloning and Characterization of Two Anthocyanin Biosynthetic Genes from Dendrobium Orchid
}

\author{
Rasika G. Mudalige-Jayawickrama, Michele M. Champagne, A. David Hieber, and \\ Adelheid R. Kuehnle ${ }^{1}$ \\ Department of Tropical Plant and Soil Sciences, University of Hawaii at Manoa, 3190 Maile Way, \\ Honolulu, HI 96822
}

\begin{abstract}
ADDitional INDEX WORDS. chalcone synthase, dihydroflavonol 4-reductase, flavonoid genes
AbStract. Two full-length cDNA clones, Den-CHS-4 and Den-DFR-1, encoding chalcone synthase (CHS) and dihydroflavonol 4-reductase (DFR) were obtained from flower bud RNA of a lavender cyanidin- accumulating Dendrobium Sw. hybrid using reverse transcription-polymerase chain reaction (RT-PCR). Northern analyses indicated that both genes are expressed in all developmental stages of buds, with highest expression in the medium-sized buds. RT-PCR analyses showed that DFR expression was confined to floral tissue while CHS was expressed in floral and vegetative tissues but not in pseudobulbs. The nucleotide sequence of a DFR clone isolated from a pale orange pelargonidin-accumulating Dendrobium hybrid was exactly the same as Den-DFR-1, ruling out the substrate specificity of DFR as a possible cause of the color difference.
\end{abstract}

Flavonoids, a diverse group of phenolic compounds, play a wide variety of roles in plants such as pollinator attraction, protection from stress and pathogens, and cell signaling in plant-microbe interactions (Koes et al., 1994). Anthocyanins are colored flavonoid glycosides, which accumulate in vacuoles giving characteristic colors to flowers and fruits. Molecular, genetic, and enzymatic aspects of anthocyanin biosynthesis by the phenylpropanoid pathway are notably well characterized in Petunia $\times$ hybrida Hort. Ex Vilm., Zea mays L., and Antirrhinum majus L. (Dooner et al., 1991; Holton and Cornish, 1995; Mol et al., 1998). Two key anthocyanin biosynthetic enzymes are chalcone synthase (CHS) and dihydroflavonol 4-reductase (DFR).

The first committed step of flavonoid biosynthesis is the formation of chalcone catalyzed by CHS. In many plants, several CHS genes constitute a small multi-gene family. Promoter regions of these genes are activated by different environmental stimuli (Martin, 1993), such as light and abiotic stress allowing the plant to accumulate anthocyanins in responsive tissues. DFR catalyzes the first specific step of anthocyanin production in which dihydroflavonols are reduced to leucoanthocyanidins, the immediate precursors of anthocyanins (Heller et al., 1985). One interesting aspect of the DFR enzyme is its substrate specificity. DFR can accept dihydrokaempferol (DHK), dihydroquercetin (DHQ), or dihydromyricetin (DHM) to form orange pelargonidin, purple cyanidin or blue delphinidin, respectively. In Petunia Juss., a well-characterized example, DFR does not reduce DHK at all, explaining the lack of pelargonidin-accumulating orange flowers (Forkman and Ruhnau, 1987; Gerats et al., 1982). Unlike CHS, DFR is represented by only a single gene in many plant species, including the two orchids Bromheadia finlaysoniana Rchb. F. and

\footnotetext{
Received for publication 6 Oct. 2004. Accepted for publication 9 Feb. 2005. This work was supported by USDA Tropical and Subtropical Agriculture Research (T-STAR) grant No. 96-34135-2480 awarded to Dr. A.R. Kuehnle. Our thanks to Ms. Stacie L. Aragon for her assistance in northern blot analyses and Dr. H. Yamamoto for his kind support and providing facilities for radioactive work. Two new gene sequences were submitted to GenBank. Accession numbers are AY741318 and AY741319 for dihydroflavonol 4-reductase gene and chalcone synthase gene, respectively.

${ }^{1}$ Corresponding author. Tel.: 808-956-2162; fax: 808-956-3894. E-mail address: heidi@hawaii.edu.
}

Cymbidium Sw. (Johnson et al., 1999; Liew et al., 1998a).

In Dendrobium, analysis of floral flavonoids found in species and hybrids identified 3'-hydroxylated cyanidin as the major pigment aglycone while pelargonidin was found to be rare and blue delphinidin was not detected (Kuehnle et al., 1997). This study identified Dendrobium x Icy Pink 'Sakura' as a unique line that accumulates $98 \%$ pelargonidin and only $2 \%$ cyanidin. This hybrid has only kaempferol derivatives as the major flavonol while $3^{\prime}$-hydroxylated quercetin derivatives were not detected. An acylated cyanidin glycoside was isolated as the major pigment found in a red-purple flower of Dendrobium 'Pramot' (Saito et al., 1994 ). Acyl group is suggested to increase the stability of the structure and the color of this anthocyanin. Nevertheless, the core anthocyanidin structure of cyanidin still remains to be the most predominant in most commercial hybrids and species.

Nucleotide sequences for any flower color genes of Dendrobium, a major commercial orchid, are lacking in accessible databases [ $\mathrm{CHS}$ was reported as cloned in abstract only in (Yong and Chua, 1990)]. Genes encoding CHS, DFR and flavanone 3hydroxylase have been isolated from other orchids (reviewed in Mudalige and Kuehnle, 2004). Our objective was to isolate the genes encoding CHS and DFR from Dendrobium and to characterize their expression patterns. This information will be useful in determining the molecular basis of flower color, including the most probable cause for the scarcity of orange-pelargonidin accumulation in Dendrobium flowers, and in identifying possible candidates for perianth-specific promoters for use in genetic engineering.

\section{Materials and Methods}

RNA EXTRACTION AND CDNA SYNTHESIS. Inflorescences and vegetative parts of lavender Dendrobium x Jaquelyn Thomas 'Uniwai Prince' (UH503) and pale orange Dendrobium x Icy Pink 'Sakura' (K1224) were harvested from greenhouse-grown plants at the Univ. of Hawaii at Manoa. Total RNA was extracted from unopened buds, flowers, pseudobulbs, leaves, and roots according to the method of Champagne and Kuehnle (2000).

cDNA was synthesized from $5 \mu \mathrm{g}$ of total RNA using 200 units of SuperScriptII RNase H- reverse transcriptase (Invitrogen, 
Carlsbad, Calif.) in 1X first strand synthesis buffer (50 mm Tris$\mathrm{HCl}, 75 \mathrm{~mm} \mathrm{KCl}, 3 \mathrm{~mm} \mathrm{MgCl}_{2}$, pH 8.3), supplemented with 0.01 $\mathrm{M}$ DTT and $0.5 \mathrm{~mm}$ dNTPs, by incubating the reaction mixture at $42{ }^{\circ} \mathrm{C}$ for $50 \mathrm{~min}$. Oligo dT ( $\mathrm{dT}_{16}$ or $\mathrm{dT}_{20}-\mathrm{T} 7$ ) primers or the gene specific primers were used for first strand cDNA synthesis (Table $1)$. The reaction was stopped by incubation of the mixture at 70 ${ }^{\circ} \mathrm{C}$ for $15 \mathrm{~min}$. The RNA template was removed by incubating the reaction mixture with 2 units of RNase $\mathrm{H}$ (Promega, Madison, Wis.) at $37{ }^{\circ} \mathrm{C}$ for $20 \mathrm{~min}$. The samples were stored at $-20{ }^{\circ} \mathrm{C}$ until utilized in PCR amplifications.

PCR WITH DEGENERATE PRIMERS TO AMPLIFY FLAVONOID GENES. Degenerate oligonucleotide primers were designed (Table 1) and synthesized (IDT, Coralville, Iowa), using the conserved regions of the GenBank DNA sequences of orthologous genes. For DFR and $C H S$, PCR reactions were carried out in a total volume of 50 $\mu \mathrm{L}$ using RedTaq DNA polymerase (Sigma, St. Louis) in a $1 \mathrm{X}$ amplification buffer [0.01 M Tris ( $\mathrm{pH} 8.3$ ), $0.05 \mathrm{M} \mathrm{KCl}, 0.01 \%$ gelatin, $0.2 \mathrm{~mm}$ dNTPs, $1.0 \mathrm{~mm} \mathrm{MgCl}_{2}$ ] using the iCycler thermal cycler (Bio-Rad, Hercules, Calif.). Flower bud cDNA made from $250 \mathrm{ng}$ of total RNA was used with 200 nм primer concentrations for each reaction. Denaturing of all PCR reactions were performed at $95^{\circ} \mathrm{C}$ while extensions were carried out at $72{ }^{\circ} \mathrm{C}$. Sequences of each primer and annealing temperatures used are listed in Table 1.

PCR products were separated on agarose gels in 1XTAE buffer (40 mm Tris-acetate, 1 mm Na $\mathrm{NaDTA}_{2}$ ). Amplified DNA fragments with expected molecular weight were excised and purified using GENECLEAN II kit (QBiogene, Carlsbad, Calif.) and ligated into pCR II-TOPO (Invitrogen).
Ligation and transformation was carried out according to the manufacturer's instructions using chemical competent Escherichia coli TOP 10 cells (Invitrogen). PCR product inserts were fully sequenced at the Univ. of Hawaii Biotechnology Core Facility.

RACE (RAPID AMPLIFICATION OF CDNA ENDS) REACTIONS. UH503 and K1224 flower bud cDNA was synthesized according to the reverse transcription protocol as described above, using $\mathrm{dT}_{20}$-T7 primer (Table 1). A gene specific primer and the T7 adapter primer were used in subsequent $3^{\prime}$ RACE reactions. Primers and the PCR conditions used in each reaction are listed in Table 1. For all RACE reactions denaturations of DNA were carried out at $95{ }^{\circ} \mathrm{C}$ and extensions were carried out at $72{ }^{\circ} \mathrm{C}$ for all Taq DNA polymerase enzymes and $68^{\circ} \mathrm{C}$ for $P f x$ DNA polymerase (Invitrogen). A skewed ratio of 10:1 gene-specific primer to adapter primer (T7) was used in all 3' RACE reactions (Bespalova et al., 1998), which was crucial for the successful amplification of the gene. Isolated PCR products were ligated into pCRII-TOPO (Invitrogen) or pGEM-Teasy (Promega) and fully sequenced.

For the $5^{\prime}$ RACE reaction of $D F R$, synthesized cDNA was cleaned in order to remove the extra dNTPs and other impurities using GENECLEAN II kit. Cleaned cDNA was boiled for $5 \mathrm{~min}$ and quickly chilled on ice. A poly-C tail was added to the singlestranded cDNA using terminal deoxyribonucleotide transferase (TdT) (Promega) in 1X tailing buffer (10 mM Tris-HCL, pH 8.4, $25 \mathrm{~mm} \mathrm{KCl}, 1.5 \mathrm{~mm} \mathrm{MgCl}_{2}$ ) supplemented with $0.8 \mathrm{~mm} \mathrm{dCTP}$ at $37{ }^{\circ} \mathrm{C}$ for $40 \mathrm{~min}$. Enzyme was inactivated by incubation at $65^{\circ} \mathrm{C}$ for $10 \mathrm{~min}$. A polyG primer with an adaptor and a gene specific primer (Table 1) were used in amplification of the $5^{\prime}$

Table 1. Primers, reverse transcription conditions, and annealing temperatures used for amplification of flavonoid genes from Dendrobium.

\begin{tabular}{|c|c|c|}
\hline $\begin{array}{l}\text { Primer } \\
\text { designation }\end{array}$ & Sequence & $\begin{array}{l}\text { Annealing temps/ } \\
\text { reaction conditions }\end{array}$ \\
\hline \multicolumn{3}{|c|}{ Reverse transcription primers } \\
\hline $\mathrm{dT}_{16}$ & ttttttttttttttt-3' & $42^{\circ} \mathrm{C}$ for $50 \mathrm{~min}$ \\
\hline $\mathrm{T}_{20}-\mathrm{T} 7$ & taatacgactcactatagggttttttttttttttttttt-3' & $42^{\circ} \mathrm{C}$ for $50 \mathrm{~min}$ \\
\hline Den-CHS-R ${ }_{\text {out }}$ & ttagagatcaagcctgggac- $3^{\prime}$ & $42^{\circ} \mathrm{C}$ for $50 \mathrm{~min}$ \\
\hline \multicolumn{3}{|c|}{ Degenerate primers } \\
\hline CHS-L & cggaattca(c/t)ca(a/g)ca(a/g)ggitg(c/t)tt(c/t)g-3' & $40^{\circ} \mathrm{C}$ for $1 \mathrm{~min}$ \\
\hline CHS-R & $\operatorname{cgggatccc}(\mathrm{a} / \mathrm{g})$ aaia $(\mathrm{a} / \mathrm{g})$ nacicccca $(\mathrm{c} / \mathrm{t}) \mathrm{t}-3^{\prime}$ & $1.0 \mathrm{mM} \mathrm{MgCl}_{2}$ \\
\hline DFR-L & cggaattcgggnccigtngtigtn- 3 & $40^{\circ} \mathrm{C}$ for $1 \mathrm{~min}$ \\
\hline DFR-R & cgggatcctacatccancengtcat $(\mathrm{c} / \mathrm{t}) \mathrm{tt}-3^{\prime}$ & $1.0 \mathrm{mM} \mathrm{MgCl}_{2}$ \\
\hline \multicolumn{3}{|l|}{ RACE primers } \\
\hline Den-CHS-6-L & gtccctgttccaactcgta-3' & $55^{\circ} \mathrm{C}$ for $1 \mathrm{~min}$ \\
\hline $\mathrm{T} 7$ & taatacgactcactata-3' & $2.0 \mathrm{mM} \mathrm{MgCl}_{2}$ \\
\hline Den-CHS- $\mathrm{R}_{\text {nest }}$ & cagtaggtggaaggttagtcc- $3^{\prime}$ & $54^{\circ} \mathrm{C}$ for $45 \mathrm{~s}$ \\
\hline AAP & ggccacgcgtcgactagtacgggggggggggggggggg- $3^{\prime}$ & First round $2.1 \mathrm{mM} \mathrm{MgCl}_{2}$ \\
\hline Den-CHS- $5_{\text {race } 2}$ & ggaaggttagtcccatctcg-3' & Same PCR conditions as the first \\
\hline AUAP & ggccacgcgtcgactagtac-3' & round amplification \\
\hline Den-DRF-L & gggttatgtggtcagggcta-3' & $55^{\circ} \mathrm{C}$ for $1 \mathrm{~min}$ \\
\hline $\mathrm{T} 7$ & taatacgactcactata-3 & $1.5 \mathrm{mM} \mathrm{MgCl}_{2}$ \\
\hline Den-DFR-R & agtcaaggtcactccagcag- $3^{\prime}$ & $55^{\circ} \mathrm{C}$ for $1 \mathrm{~min}$ \\
\hline AAP & ggccacgcgtcgactagtacgggggggggggggggggg-3' & First round $1.5 \mathrm{mM} \mathrm{MgCl}_{2}$ \\
\hline Den-DFR-R & agtcaaggtcactccagcag-3' & Same PCR conditions as the first \\
\hline AUAP & ggccacgcgtcgactagtac- $3^{\prime}$ & round amplification \\
\hline \multicolumn{3}{|c|}{ RT-PCR primers } \\
\hline Den-DFR-5'ext & aactggcgttgaggagagag-3' & $55^{\circ} \mathrm{C}$ for $1 \mathrm{~min}$ \\
\hline Den-DFR-3'utr & acaacaacattagcttctccttt-3' & $1.5 \mathrm{mM} \mathrm{MgCl}_{2}$ \\
\hline Den-CHS-PfxL & ggcaatggaagagatcagg- $3^{\prime}$ & $55^{\circ} \mathrm{C}$ for $1 \mathrm{~min}$ \\
\hline Den-CHS-PfxR & gcaccagcaatcggaacgc-3 & $1.5 \mathrm{mM} \mathrm{MgCl}_{2}$ \\
\hline
\end{tabular}

$\mathrm{z} \mathrm{i}=$ inosine, a substitute for $(\mathrm{a} / \mathrm{c} / \mathrm{g} / \mathrm{t})$ to reduce degeneracy in primers, $\mathrm{n}=\mathrm{a} / \mathrm{c} / \mathrm{g} / \mathrm{t}$. 
end of the gene. The primary amplification was re-amplified in a second PCR with the same primer combination to generate a sufficient amount of products for cloning and sequencing. For the $5^{\prime}$ RACE reaction of $C H S$ gene the RACE kit from Invitrogen was used with the primers and PCR conditions listed in Table 1. Later, full clones were amplified using high fidelity Platinum $P f x$ DNA polymerase and fully sequenced. A phylogenetic tree was drawn from Phylogenetic Inference Package (PHYLIP version 3.5c; Felsenstein, 1993) showing relationships among the nucleotide sequences of $D F R$ genes from different plant species. Sequence alignment was performed with CLUSTAL W version 3.2 (Thompson et al., 1994) with a gap penalty of 3 .

RADIOACTIVE PROBE SYNTHESIS FOR NORTHERN HYBRIDIZATION. The cDNA inserts of the flavonoid genes were isolated by restriction digestion of the clones with EcoRI enzyme and separation on $1 \%$ agarose gel. DNA fragments were purified (GENECLEAN II kit) and $20 \mathrm{ng}$ were labeled with $\alpha^{32} \mathrm{P}$-ATP using random primer labeling (Prime a Gene Kit; Promega). Labeled product was cleaned using Elutip-D column (Schleicher and Shuell, Keene, N.H.). Cleaned probe was added to the hybridization buffer at a concentration of $1 \times 10^{6}$ counts $/ \mathrm{min}$ per $\mathrm{mL}$ of buffer.

NORTHERN BLOT HYBRIDIZATION. Floral buds and flowers from harvested inflorescences of UH503 and K1224 were divided into 10 different developmental stages, stage 1 being the most immature (Table 2). RNA was extracted from bud/flower stages and mature leaves according to Champagne and Kuehnle (2000). Total RNA $(10 \mu \mathrm{g})$ from each stage was size fractionated by a standard $2 \%$ formaldehyde agarose $(0.9 \%)$ gel electrophoresis (1X MOPS buffer). RNA was transferred overnight onto Nytran Supercharge nylon membrane (Schleicher and Schuell) by downward capillary transfer using alkaline transfer buffer $(3 \mathrm{M} \mathrm{NaCl}, 0.01 \mathrm{~N} \mathrm{NaOH})$. Hybridization and washing was done according to Church and Gilbert (1984) but using $0.25 \mathrm{M} \mathrm{Na}_{2} \mathrm{HPO}_{4} \cdot 7 \mathrm{H}_{2} \mathrm{O}$ in hybridization buffer at $\mathrm{pH}$ 7.4. Membranes were hybridized with ${ }^{32} \mathrm{P}$ labeled DNA probes at $60{ }^{\circ} \mathrm{C}$ overnight in hybridization buffer $[7 \%$ SDS, $1 \%$ fatty acid free bovine serum albumin (BSA) (Sigma), $1 \mathrm{~mm}$ $\mathrm{Na}_{2}$ EDTA $\left.2 \mathrm{H}_{2} \mathrm{O}, 0.25 \mathrm{M} \mathrm{Na} \mathrm{HPO}_{4} \cdot 7 \mathrm{H}_{2} \mathrm{O}(\mathrm{pH} 7.4)\right]$. Blots were washed twice at $60{ }^{\circ} \mathrm{C}$ for $10 \mathrm{~min}$, using phosphate wash buffer with BSA $\left[0.5 \%\right.$ BSA, 1 mm Na $\mathrm{EDTA}_{2} \cdot 2 \mathrm{H}_{2} \mathrm{O}$, 5\% SDS, $40 \mathrm{~mm}$ $\left.\mathrm{Na}_{2} \mathrm{HPO}_{4} \cdot 7 \mathrm{H}_{2} \mathrm{O}(\mathrm{pH} 7.4)\right]$. The final two washes were done at $60{ }^{\circ} \mathrm{C}$ for $20 \mathrm{~min}$ using phosphate buffer without BSA [1 mM $\mathrm{Na}_{2}$ EDTA $2 \mathrm{H}_{2} \mathrm{O}, 1 \% \mathrm{SDS}, 40 \mathrm{~mm} \mathrm{Na} \mathrm{HPO}_{4} \cdot 7 \mathrm{H}_{2} \mathrm{O}(\mathrm{pH}$ 7.4)]. We have used high stringency conditions to avoid any cross reaction of Den-CHS-4 probe with other transcripts with high similarity

Table 2. Description of the bud and flower stages of Dendrobium x Jaquelyn Thomas 'Uniwai Prince' used in temporal expression of flower color genes.

\begin{tabular}{|c|c|c|}
\hline $\begin{array}{l}\text { Bud/flower } \\
\text { stage }\end{array}$ & Length $(\mathrm{cm})$ & Description and position on the raceme \\
\hline 1 & $1.3-1.5$ & $\begin{array}{l}\text { Most immature buds, light green adaxial surface with a little purple } \\
\text { color on the abaxial surface. }\end{array}$ \\
\hline 2 & $1.5-1.7$ & $\begin{array}{l}\text { Small buds, adaxial surface still green, most of the abaxial surface } \\
\text { turned purple. }\end{array}$ \\
\hline 3 & $1.7-1.9$ & Medium-small buds, adaxial surface of perianth turning dark purple \\
\hline 4 & $1.9-2.1$ & Medium size buds, dark purple perianth on both surfaces. \\
\hline 5 & $2.1-2.3$ & Medium-large unopened buds, dark purple. \\
\hline 6 & $2.4-2.8$ & $\begin{array}{l}\text { Most mature buds, unopened, dark purple on both adaxial and } \\
\text { abaxial surfaces of perianth. }\end{array}$ \\
\hline 7 & Not measured & Flowers just opened (half open). \\
\hline 8 & Not measured & $\begin{array}{l}\text { Flowers fully opened, dark purple perianth, one position below } \\
\text { stage } 7 \text { flower. }\end{array}$ \\
\hline 9 & Not measured & Open flower, two flowers below stage 7 on the raceme, dark purple. \\
\hline 10 & Not measured & Older flower, three flowers below stage 7 , dark purple. \\
\hline
\end{tabular}

to CHS. Signals were detected after $3 \mathrm{~d}$ of exposure by autoradiography for UH503 or using a Bio-Rad Personal Molecular Imager FX for K1224.

RT-PCR ANALYSES (REVERSE TRANSCRIPTION-PCR). cDNA samples synthesized from total RNA of roots, pseudobulbs, leaves, flowers, and buds of UH503 and K1224 Dendrobium orchids were used to amplify DFR and CHS transcripts using gene-specific primers and PCR conditions listed in Table 1. The resulting products were ligated to pGEM-T easy vector and sequenced to verify their identity.

\section{Results}

Cloning and Sequence analysis of Flavonoid biosynthetic GENES. Dihydroflavonol 4-reductase. We chose a typical cyanidin accumulating line, Dendrobium x Jaquelyn Thomas 'Uniwai Prince' (UH503), and a rare pelargonidin accumulating line Dendrobium x Icy Pink 'Sakura' (K1224), for isolation of the DFR gene. Two partial cDNA clones were isolated from UH503 and K1224 flower bud cDNA and amplified using 5' RACE and 3' RACE techniques. Overlapping regions (400 bp) of the two partial clones were identical to each other. Later, a full-length clone of $1320 \mathrm{bp}$ was amplified with the high fidelity $P f x$ DNA polymerase and fully sequenced (GenBank accession No. AY741319). The nucleotide sequence of the DFR clone isolated from Dendrobium Icy Pink 'Sakura' (K1224) was identical to the clone isolated from UH503 despite their flower color difference. The first ATG found 30 nucleotides downstream from the $5^{\prime}$ end of the clone is the most probable start codon since it is immediately preceded by AAAGAAATGG which resembles the plant consensus sequence (Joshi, 1987). A polyadenylation signal, AATAAA, was found 159 nucleotides downstream from the TGA stop codon. A polypeptide of 352 amino acid residues with a molecular mass of $39.7 \mathrm{kD}$ was deduced from the longest open reading frame (ORF) and was designated as Den-DFR-1.

The nucleotide sequence of Den-DFR-1 revealed a similarity ranging from $65 \%$ to $86 \%$ when compared to nineteen other plant DFR sequences available in GenBank. A phylogenetic tree based on CLUSTAL W alignment shows that Den-DFR-1 is closest to the DFR clones from the two orchids, Bromheadia finlaysoniana and Cymbidium, with $86 \%$ and $83 \%$ identity, respectively (Fig. 1). The closest nonorchid sequence, from Lilium L. hybrid (Liliaceae), was $56 \%$ identical to Den-DFR-1. The phylogenetic tree shows all monocotyledonous sequences cluster into a single branch showing their common ancestry, while dicotyledonous sequences clustered into two clades.

Comparison of the deduced amino acid sequence of Den-DFR- 1 with those of the two orchids, Bromheadia and Cymbidium, showed $86 \%$ and $82 \%$ identity, respectively. Lilium hybrid and Zea mays (Poaceae) shared $72 \%$ and $67 \%$ identity with the Dendrobium. We have compared the putative region that determines the substrate specificity of DFR as proposed by Beld et al. (1989) and Johnson et al. (1999), among eight different DFR enzymes including Dendrobium (Fig. 2). DFR of five species, Rosa L. hybrid, Dianthus 


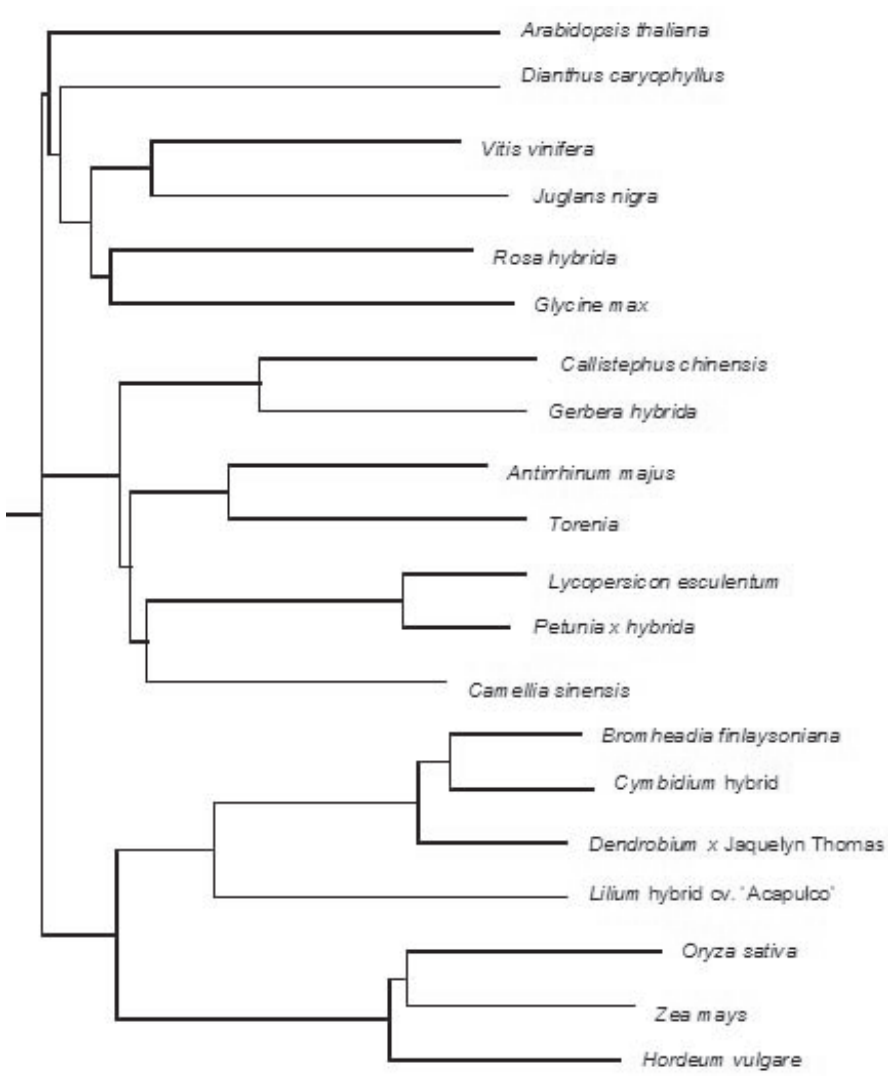

Fig. 1. Phylogenetic tree showing relationships among the nucleotide sequences of $D F R$ genes from different plant species. GenBank accession numbers for each species are listed below: A. thaliana (L.) Heynh.-M86359; D. caryophyllus L.Z67983; V. vinifera L.-X75964; J. nigra L.-AJ278459; Rosa hybrida-D85102; C. Chinensis (L.) Benth.-Z67981; G. hybrida-Z17221; A. majus L.-X15536; T. hybrida-AB012924; L. esculentum Mill.-Z18277; P. ×hybrida-AF233639; C. sinensis (L.) Kuntze-AB018686; G. $\max$ (L.) Merr-AF167556; B. filaysoniana Rchb.f.-AF007096; Cymbidium hybrida-AF017451; Lilium hybrid-AF169801; O. sativa L.-AB003496; Z. mays L.-X05068; H. vulgare L.-S69616.

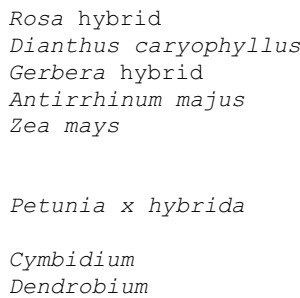

133

SVNVEETQKPVYNESNWSDVEFCRRVKMTGWMYFAS TVNVEATOKPVYDETCWSDLDFIRSVKMTGWMYFVS TVNGQEKQLHVYDESHWSDLDF I YSKKMTAWMYFVS TVNVEEHQKPVYDETDSSDMDF INSKKMTGWMYFVS TVNLEERQRPVYDEESWTDVDFCRRVKMTGWMYFVS

TLDVQEQQKLEYYDQTSWSDLDF I YAKKMTGWMYFAS TVNVEEHQATVYDESSWSDLDFVTRVKMTGWMYFVS TVNVEEHQAAVYDESCWSDLDFVNRVKMTGWMYFLS
Fig. 2. Region of substrate specificity of dihydroflavonol reductase enzyme from six different plant species compared with the two orchid sequences. The first five enzymes listed are known to accept DHK as a substrate. Petunia $\times$ hybrida and Cymbidium DFR do not accept DHK as a substrate. Underlined amino acid residues are different in Petunia but conserved in all other enzymes including Cymbidium despite the similarity of substrate specificity of these two enzymes. Dendrobium DFR is also similar to Cymbidium in this critical region.

caryophyllus L., Gerbera L. hybrid, Antirrhinum majus, and Zea mays were already known to accept DHK as a substrate while $P e$ tunia and Cymbidium does not accept DHK (Johnson et al., 1999, 2001). Our comparison showed that the four amino acid residues that are unique to Petunia DFR are not shared by Dendrobium or Cymbidium DFR sequences (Fig. 2). In fact, these four amino acid residues are conserved among the five DHK accepting enzymes and the two orchid DFR sequences despite the common substrate specificity shared by Cymbidium and Petunia.

Southern analysis of genomic DNA from young leaves of the two Dendrobium hybrids, UH503 and K1224, indicated that there is only a single copy of DFR gene present in both hybrids (data not shown). This result is similar to the other two orchids, Cymbidium and Bromheadia (Johnson et al., 1999; Liew et al., 1998a). However, we cannot eliminate the possibility of the presence of more than one copy since both these hybrids are polyploids.

Chalcone synthase. PCR with degenerate primers resulted in the isolation of two partial clones from Dendrobium $\times$ Jaqueyn Thomas 'Uniwai Prince', $C H S-6$ and $C H S-9$, with significant similarity to a Phalaenopsis Blume 'True Lady' CHS homolog (A.R. Kuehnle and M.M. Champagne, unpublished data). Genespecific primers designed from the sequence data of $\mathrm{CHS}-6$ and CHS-9 were used to isolate the $3^{\prime}$ ends of each clone. We were able to obtain the $3^{\prime}$ end of a chalcone synthase gene using the primers designed from the $C H S$ - 6 clone. Surprisingly, this partial clone (Den-CHS-11) was only $70 \%$ similar to the CHS-6 partial clone. A different set of primers designed from Den-CHS-11 enabled isolation of a full-length $\mathrm{CHS}$ clone Den-CHS-4 (GenBank accession No. AY741319).

The 3' RACE performed with primers designed from the CHS-9 sequence resulted in a $500 \mathrm{bp}$ fragment (Mudalige, 2003), with high similarity to bibenzyl synthase, a close relative of CHS that catalyzes a similar chemical reaction. Bibenzyl synthase participates in synthesizing a repertoire of chemical defense compounds known as phytoalexins and hence may be a valuable tool in disease resistance. A closer inspection of the $C H S$ homolgue from Phalaenopsis sp. 'True Lady' (Hsu et al., 1997) (GenBank No. U88077, protein ID AAB650941) with BLAST searching revealed this Phalaenopsis cDNAclone is indeed more similar to the bibenzyl synthase genes from Bromheadia and other Phalaenopsis hybrids than to CHS from these two orchids.

The most closely related $\mathrm{CHS}$ sequence, from the orchid Bromheadia finlaysoniana, is $81 \%$ and $94 \%$ identical to Den-CHS-4 at the nucleotide and amino acid levels, respectively (Table 3 ). The closest nonorchid sequence is that of Lilium hybrida with $85 \%$ identity ( $93 \%$ similarity) in deduced amino acid sequences. Amino acid sequences of CHS from 25 other plant species have similarly high identity, indicating that chalcone synthase is highly conserved among different plant species (Table 3).

GENE EXPRESSION BY NORTHERN ANALYSES. Temporal expression of DFR and CHS in the developing inflorescences of UH503 showed that both transcripts are most abundant in medium sized flower buds (stages 3 and 4) with levels declining to a nearly undetectable level as the flowers open (Fig. 3). A similar temporal expression pattern was observed for DFR and $C H S$ in the developing flowers of K1224 (Fig. 4). We have used high stringency washes to minimize any cross reactions of Den-CHS-4 with other CHS-like mRNAs. The mRNA of the two other Dendrobium clones, $C H S-6$ and $C H S-9$, hybridized at a higher molecular weight than Den-CHS-4 (data not shown).

RT-PCR analysis has shown that DFR transcripts could be amplified from the total RNA of open flowers as well as unopened buds in both genotypes (Fig. 5). The DFR transcripts could not be amplified from vegetative parts such as leaves, pseudobulbs or roots in UH503 and K1224 (Fig. 5). Contrary to DFR, CHS transcripts could be amplified from all vegetative tissues except pseudobulbs. 
Table 3. Comparison of deduced amino acid sequence of Dendrobium chalcone synthase clone (Den-CHS-4) with chalcone synthase from other plants at the amino acid level.

\begin{tabular}{|c|c|c|c|c|}
\hline Plant species & Common name & $\begin{array}{c}\text { GenBank } \\
\text { accession no. }\end{array}$ & $\begin{array}{l}\text { Length of the } \\
\text { sequence }\end{array}$ & Identity $(\%)^{z}$ \\
\hline Dendrobium Sw. (UH503) & Dendrobium & --------------- & 395 & 100 \\
\hline Bromheadia finlaysoniana $\mathrm{Rchb} . \mathrm{f}$. & Seraman & AF007097 & 394 & 94 \\
\hline Lilium $L$. hybrid & Lily & AF169798 & 393 & 85 \\
\hline Sorghum bicolor $(\mathrm{L}$.$) Moench$ & Sorghum & AF152553 & 401 & 84 \\
\hline Petunia xhybrida hort. Ex Vilm & Petunia & X14597 & 389 & 84 \\
\hline Zea mays L. & Corn & X60205 & 400 & 83 \\
\hline Oryza sativa $\mathrm{L}$. & Rice & X89859 & 398 & 82 \\
\hline Vitis vinifera $\mathrm{L}$. & Grape & $\mathrm{AB} 066275$ & 393 & 85 \\
\hline Torenia L. hybrid & Torenia & AB012923 & 388 & 84 \\
\hline Gerbera L. hybrid & Gerbera & Z38096 & 398 & 83 \\
\hline Nicotiana tabacum $\mathrm{L}$. & Tobacco & AF11783 & 389 & 83 \\
\hline Camellia sinensis (L.) Kuntze & Tea & D26593 & 389 & 83 \\
\hline Catharanthus roseus (L.) G. Don & Periwinkle & AJ131813 & 389 & 83 \\
\hline Callistephus chinensis (L.) Benth. & China aster & Z67988 & 398 & 82 \\
\hline $\begin{array}{l}\text { Petroselinum crispum (Mill.) Nyman } \\
\text { ex A.W. Hill }\end{array}$ & Parsley & V01538 & 398 & 83 \\
\hline Daucus carota L. & Carrot & AJ006780 & 397 & 82 \\
\hline Solanum tuberosum L. & Potato & U47740 & 389 & 83 \\
\hline Glycine $\max$ (L.) Merr. & Soybean & L07647 & 388 & 83 \\
\hline Antirrhinum majus L. & Snapdragon & $\mathrm{X} 03710$ & 390 & 82 \\
\hline Rosa L. hybrid cv. Kardinal & Rose & AB038246 & 389 & 82 \\
\hline Lycopersicon esculentum Mill. & Tomato & X55194 & 389 & 82 \\
\hline Hordeum vulgare L. & Barley & X58339 & 398 & 81 \\
\hline Matthiola incana (L.) R. Br. & Stock & AJ427536 & 394 & 81 \\
\hline Brassica napus L. & Kale, rape, rutabaga & AF076335 & 394 & 80 \\
\hline Hydrangea macrophylla (Thunb.) Ser. & Hydrangea & AF456448 & 389 & 80 \\
\hline Arabidopsis thaliana (L.) Heynh. & Arabidopsis & AY090376 & 395 & 80 \\
\hline
\end{tabular}

${ }^{{ }^{2}}$ Sequences are aligned with CLUSTAL W (Thompson et al., 1994) program via San Diego Supercomputer Center Biology Workbench.
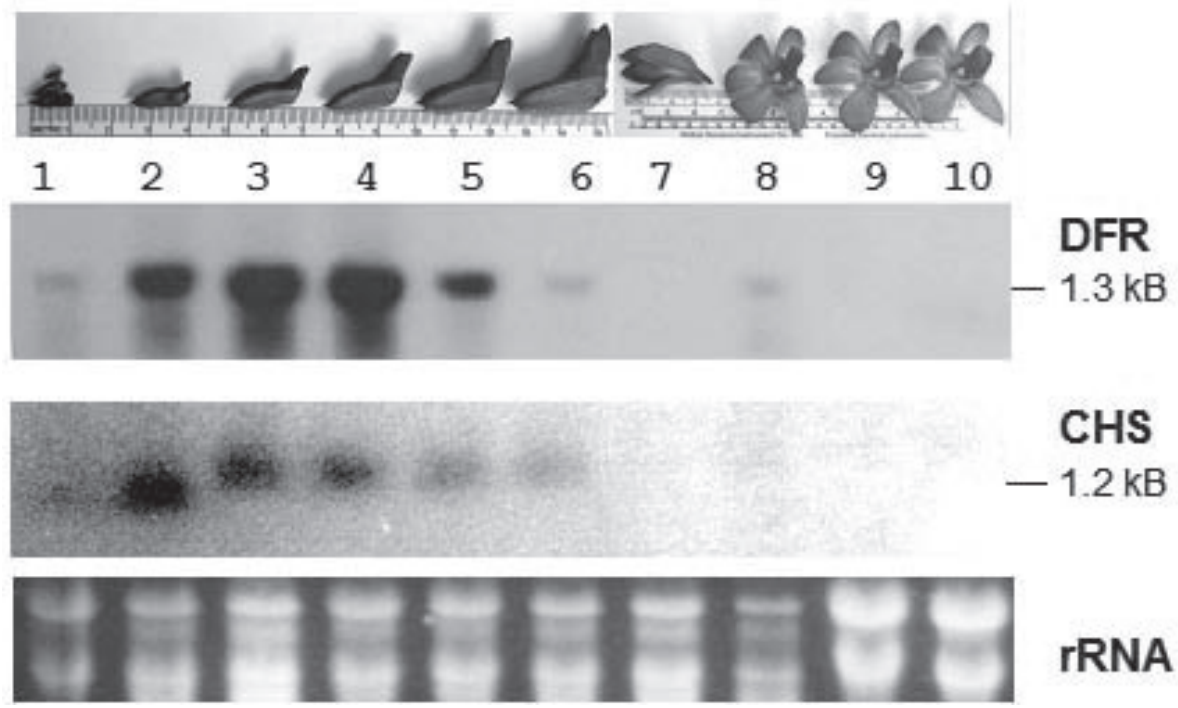

Fig. 3. Northern blots showing temporal expression of DFR and $C H S$ mRNA in the developing inflorescence of Dendrobium x Jaquelyn Thomas 'Uniwai Prince' (UH503). Upper panel shows the unopened buds and flowers used in RNA extraction, sorted according to size and the position on raceme (smallest bud is at the end of raceme). Total RNA (10 $\mu \mathrm{g} / \mathrm{lane})$ was hybridized with ${ }^{32} \mathrm{P}-$-labeled denatured probes of Den-DFR-1 or Den-CHS-4. rRNA bands shown in the bottom panel indicate the loading levels of RNA.

\section{Discussion}

We have successfully isolated full-length cDNA clones encoding DFR and CHS from Dendrobium. Analysis of deduced amino acid sequence of Den-CHS-4 shows that it is highly conserved across 25 plant species. Bromheadia CHS, the clos- est to Dendrobium sequence, demonstrates a $94 \%$ identity at the amino acid level. However, the presence of other enzymes with sequence similarity such as bibenzyl synthase, stilbene synthase and acridone synthase makes it difficult to identify the genes encoding CHS by sequence similarity alone (Helariutta et al., 1995; Liew et al., 1998b). Stilbene synthase uses exactly the 


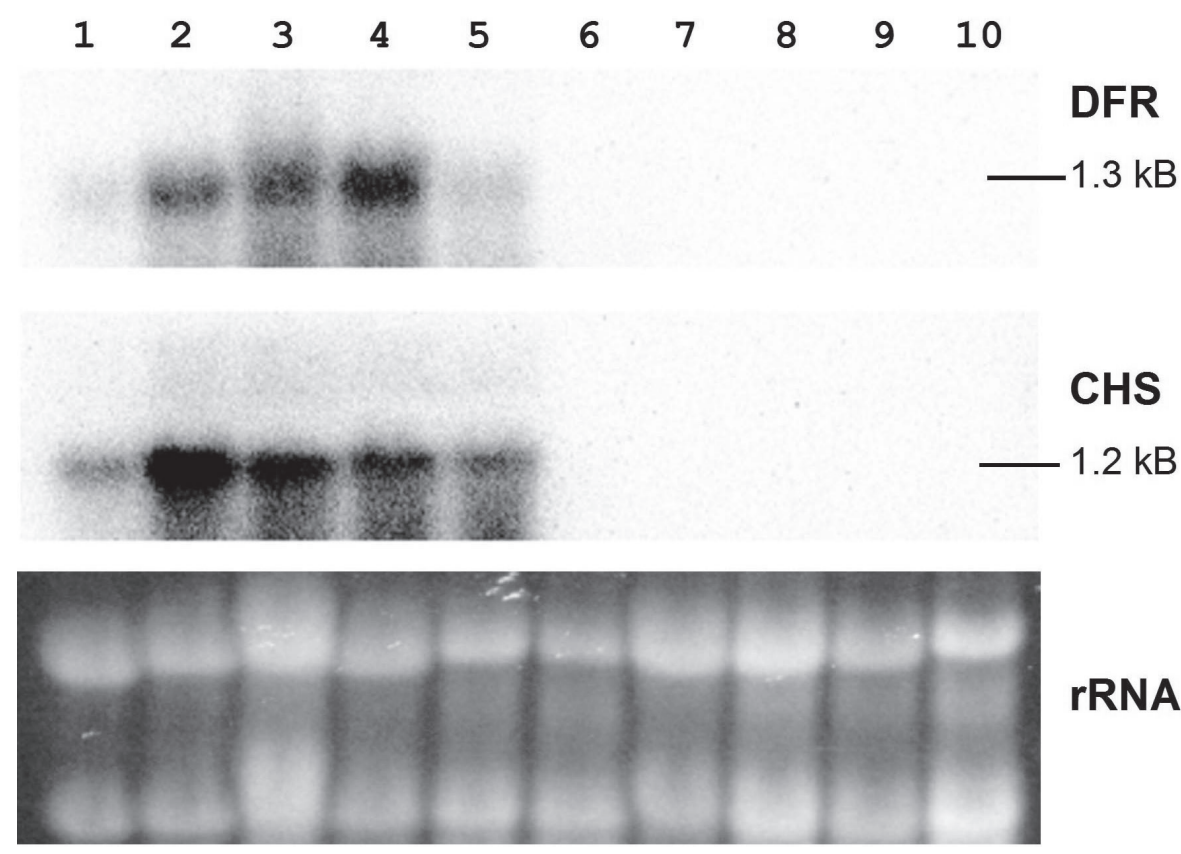

Fig. 4. Northern blots showing temporal expression of DFR and $C H S$ in the developing inflorescence of Dendrobium x Icy Pink 'Sakura' (K1224). Total RNA (10 $\mu \mathrm{g} /$ lane) from 10 bud and flower stages were hybridized with ${ }^{32} \mathrm{P}-1$ labeled denatured cDNA probes of Den-DFR-1 or Den-CHS-4. The bottom panel indicates the loading levels of RNA in ethidium bromide stained rRNA bands. 1 to $6=$ flower buds from youngest to most mature; 7 to $10=$ open flowers

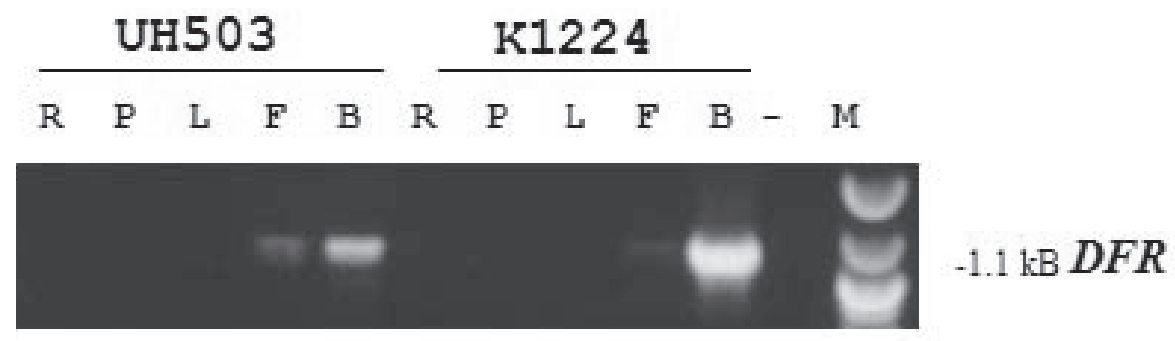

UH503

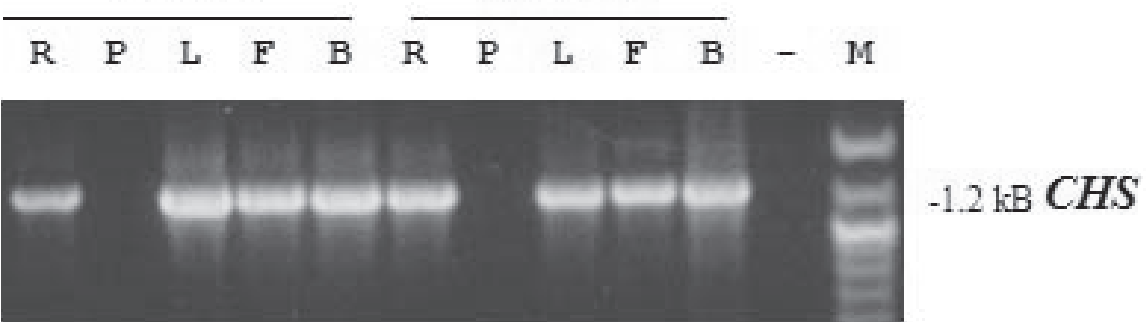

Fig. 5. Agarose gel of RT-PCR products showing the spatial expression of DFR and $C H S$ in different tissues of Dendrobium hybrids UH503 and K1224. cDNA synthesized from $200 \mathrm{ng}$ of total RNA was amplified with gene specific primers for DFR and $C H S$ to detect the presence of transcripts in roots (R), pseudobulbs (p), leaves (L), open flowers (F) and Buds (B). $\mathrm{M}=$ molecular weight marker.

same substrates as CHS to form a different product, resveratrol, through a different cyclization reaction. Bibenzyl synthase utilizes $m$-hydroxyphenylpropionyl-CoA instead of coumaryl CoA to synthesize $3,3^{\prime}, 5$-trihydroxybibenzyl by a similar reaction to CHS. Genes encoding all three enzymes share a high homology due to the similarity of their catalysis.

Northern analysis supplements our sequence data, with the strong expression of Den-CHS-4 in flower buds. This is consistent with the results of Bromheadia (Liew et al., 1998b). In many plants $C H S$ is represented by a multi-gene family, with different members of the gene family responding to different environmental stimuli such as UV light (Hirner et al., 2001; Jenkins et al., 2001; Loyall et al., 2000), low temperature (Hasegawa et al, 2001), pathogen attack (Seki et al., 1999), wounding and phytohormones (Tamari et al., 1995). Although the clone we have isolated seemed to be strongly expressed in floral buds, the presence of transcripts in all other tissues indicates that this enzyme is not exclusively expressed in floral tissue. This is not surprising since CHS is the primary enzyme that provides the building blocks of all flavonoids and is expected to be active in most tissues. In contrast, $D F R$ expression is restricted only to floral tissue at a specific developmental stage of the flower bud.

Regulatory genes directly control CHS activity in many plants (reviewed in Martin and Gerats, 1993; Mol et al., 1998). Recessive alleles of the $C 2$ gene of Zea mays (Dooner, 1983), F in Matthiola incana (L.) R. Br. (Spiribille and Forkmann, 1981), and Niv in Antirrhinum majus (Spiribille and Forkmann, 1982), are unable to activate the transcription of CHS gene and block the CHS activity and anthocyanin synthesis in the respective plant. These color regulatory genes encode flower specific bHLH, Myb and Myc type transcription factors that activate the transcription of anthocyanin biosynthetic genes (reviewed in Mol et al., 1998). Genetic studies in our classical breeding program suggest that both structural and regulatory genes may be involved in breeding of white Dendrobium, producing color by complementary gene action when certain whites are crossed with other whites (Kamemoto et al., 1999). We hypothesize that when a white flowered structural mutant is crossed with any other white flowered (different) structural mutant will result in complementation to form color; likewise any regulatory mutant with any other white regulatory mutant or a combination amongst them will lead to color complementation. The identification of the key genes $C H S$ and $D F R$ will now allow the breeder to screen white phenotypes for the expression profile of these biosynthetic genes, thereby determining the role these genes play in the complementary gene action of white $\mathbf{X}$ white crosses.

Sequence analysis revealed Den-DFR 1 shares $83 \%$ identity with the Cymbidium DFR gene, whose corresponding enzyme does not efficiently reduce DHK to form orange pelargonidin (Johnson et al., 1999). A putative region that determines the substrate specificity of DFR based on sequence alignment of petunia, maize and snapdragon, was proposed by Beld et al. (1989). Johnson et al. (2001) further identified four unique amino acid residues from this region that determine the substrate specificity 
of Petunia DFR. However, these four amino acids are not shared by Cymbidium and Petunia, despite their similarity in substrate specificity ruling out the possibility of these residues as the region of substrate specificity for the Cymbidium DFR. These four residues are conserved among all DHK accepting enzymes as well as the Dendrobium and Cymbidium DFR. Therefore, our results agree with the hypothesis that the substrate specificity of orchid DFR may be determined by another region of the enzyme (Johnson et al., 2001), different from that has been described in Petunia.

Most Dendrobium hybrids contain cyanidin and peonidin as their major anthocyanidin (Kuehnle et al., 1997). Two unique lines, $D$. x Icy Pink 'Sakura'(K1224) and D. x Waianae Blush, have pelargonidin as their major anthocyanidin and the amount of cyanidin is limited to only $2 \%$ of total anthocyanidin content. The pedigree of K1224 shows that this unique color phenotype occurred in the progeny of a cross between white and two-tone lavender parents (Kamemoto et al., 1999). It is theorized that such a color change could occur due to two reasons: 1) a mutation of the DFR enzyme could change its substrate specificity from dihydroquercetin to dihydrokaempferol, or 2) a mutation of the flavonoid 3'-hydroxylase $\left(\mathrm{F}^{\prime} \mathrm{H}\right)$ enzyme could reduce the amount of available DHQ making DHK the most abundant substrate available for DFR. Sequence comparison of $D F R$ from a typical lavender phenotype, UH503, with that of K1224 (pelargonidin accumulating line) has shown that the two sequences are identical, eliminating the substrate specificity of DFR as the reason for color difference. Chemical analysis of K1224 has detected only kaempferol derivatives as the major flavonols, with no detectable levels of 3'-hydroxylated quercetin derivatives, suggesting very low or no activity of F3' $\mathrm{H}$ in flowers (Kuehnle et al., 1997). Therefore, the most probable reason for the pelargonidin accumulation in K1224 is a mutation of F3' $\mathrm{H}$ leading to a reduction of F3'H activity, promoting Dendrobium DFR to accept DHK, the less preferred substrate, resulting in low levels of pelargonidin synthesis. Interestingly, spontaneous mutations in the F ${ }^{\prime}{ }^{\prime} \mathrm{H}$ gene in three species of Ipomoea L. confer reddish color due to the accumulation of pelargonidin instead of cyanidin in their flowers (Hoshino et al., 2003).

The spatial and temporal expression patterns of Den-DFR-1 revealed that it is highly specific to floral tissue and coincides with the color development in buds. Therefore, the promoter region of Den-DFR-1 may be an ideal candidate for a perianth-specific promoter for flower color manipulation. Furthermore, a potential for the increase of pelargonidin accumulation in Dendrobium flowers with the addition of a DFR enzyme that readily accepts DHK to form true orange flowers might provide an opportunity to increase the color range for this important ornamental.

\section{Literature Cited}

Beld, M., C. Martin, H. Huits, A.R. Stuitje, and A.G.M. Gerats. 1989. Flavonoid synthesis in Petunia hybrida: Partial characterization of dihydroflavonol-4-reductase genes. Plant Mol. Biol. 13:491-502.

Bespalova, I.N., S. Adkins, and M. Burmeister. 1998. 3’ RACE: Skewed ratio of specific to general PCR primers improves yield and specificity. BioTechniques 24:575-577.

Champagne, M.M. and A.R. Kuehnle. 2000. An effective method for isolating RNA from tissues of Dendrobium. Lindleyana 15:165-168. Church, G.M. and W. Gilbert. 1984. Genomic sequencing. Proc. Natl. Acad. Sci. 81:1991-1995.

Dooner, H.K. 1983. Coordinate genetic regulation of flavonoid biosynthetic enzymes in maize. Mol. Gen. Genet. 189:136-141.

Dooner, H.K., T.P. Robbins, and R.A. Jorgenson. 1991. Genetic and developmental control of anthocyanin biosynthesis. Ann. Rev. Genet. 25:173-199.
Felsenstein, J. 1993. PHYLIP (Phylogeny Inference Package) version 3.5c. Dept. of Genetics, Univ. of Washington, Seattle.

Forkman, G. and B. Ruhnau. 1987. Distinct substrate specificity of dihydroflavonol-4-reductase from flowers of Petunia hybrida. Z. Naturforsch 42c:1146-1148.

Gerats, A.G.H., P. de Vlaming, M. Doodeman, B. Al, and A.W. Schram. 1982. Genetic control of the conversion of dihydroflavonols into flavonols and anthocyanins in flowers of Petunia hybrida. Planta 155:364-368.

Hasegawa, H., T. Fukasawa-Akada, T. Okuno, M. Niizeki, and M. Suzuki. 2001. Anthocyanin accumulation and related gene expression in japanese parsley (Oenanthe stolonifera, DC.) induced by low temperature. Plant Physiol. 158:71-78.

Helariutta, Y., P. Elomaa, M. Kotilainen, R.J. Griesbach, J. Schroder, and T.H. Teeri. 1995. Chalcone synthase-like genes active during corolla development are differentially expressed and encode enzymes with different catalytic properties in Gerbera hybrida (Asteraceae). Plant Mol. Biol. 28:47-60.

Heller, W., G. Forkmann, L. Britsch, and H. Griesbach. 1985. Enzymatic reduction of (+)-dihydroflavonols to flavan-3, 4-cis-diols with flower extracts from Matthiola incana and its role in anthocyanin biosynthesis. Planta 165:284-287.

Hirner, A.A., S. Veit, and H.U. Seitz. 2001. Regulation of anthocyanin biosynthesis in UV-A irradiated cell cultures of carrot and in organs of intact carrot plants. Plant Sci. 161:315-322.

Holton, T.A. and E.C. Cornish. 1995. Genetics and biochemistry of flavonoid biosynthesis. Plant Cell 7:1071-1083.

Hoshino, A., Y. Morita, J.D. Choi, N. Saito, K. Toki, Y. Tanaka, and S. Iida. 2003. Spontaneous mutations of the flavonoid 3'-hydroxylase gene conferring reddish flowers in the three morning glory species. Plant Cell Physiol. 44:990-1001.

Hsu, W.S., Y.Y. Do, and P.L. Huang. 1997. Isolation and characterization of a cDNA encoding chalcone synthase homolog from Phalaenopsis, PGR97-068. Plant Physiol. 113:1465.

Jenkins, G.I., J.C. Long, H.K. Wade, M.R. Shenton, and T.N. Bibikova. 2001. UV and blue light signaling: Pathways regulating chalcone synthase gene expression in Arabidopsis. New Phytol. 151:121-131.

Johnson, E.T., S. Ryu, H. Yi, B. Shin, H. Cheong, and G. Choi. 2001. Alteration of a single amino acid changes the substrate specificity of dihydroflavonol 4-reductase. Plant J. 25:325-333.

Johnson, E.T., H. Yi, B. Shin, B.J. Oh, H. Cheong, and G. Choi. 1999. Cymbidium hybrida dihydroflavonol 4-reductase does not efficiently reduce dihydrokaempferol to produce orange pelargonidin-type anthocyanins. Plant J. 19:81-85.

Joshi, C.P. 1987. An inspection of the domain between putative TATA box and translation site in 79 plant genes. Nucleic Acids Res. 15:6643-6653.

Kamemoto, H., T.D. Amore, and A.R. Kuehnle. 1999. Genetics of some characters, in breeding Dendrobium orchids in Hawaii, pp. 87-106. Univ. of Hawaii Press, Honolulu.

Koes, R.E., F. Quattrocchio, and J.N.M. Mol. 1994. The flavonoid biosynthetic pathway in plants: Function and evolution. BioEssays 16:123-132.

Kuehnle, A.R., D.H. Lewis, K.R. Markham, K.A. Mitchell, K.M. Davies, and B.R. Jordan. 1997. Floral flavonoids and pH in Dendrobium orchid species and hybrids. Euphytica 95:187-194.

Liew, C.F., C.S. Loh, C.J. Goh, and S.H. Lim. 1998a. The isolation, molecular characterization and expression of dihydroflavonol 4-reductase cDNA in the orchid, Bromheadia finlaysoniana. Plant Sci. 135:161-169.

Liew, C.F., C.J. Goh, C.S. Loh, and S.H. Lim. 1998b. Cloning and characterization of full-length cDNA clones encoding chalcone synthase from the orchid Bromheadia finlaysoniana. Plant Physiol. Biochem. 36:647-656

Loyall, L., K. Uchida, S. Braun, M. Furuya, and H. Frohenmeyer. 2000. Glutathione and a UV light-induced glutathione S-transferase are involved in signaling to chalcone synthase in cell cultures. Plant Cell 12:1939-1950.

Martin, C.R. 1993. Structure, function and regulation of the chalcone 
synthase, p. 233-284. In: K.W. Joen and J. Jarwick (eds.). International review of cytology - A survey of cell biology. Academic, New York.

Martin, C. and T. Gerats. 1993. Control of pigment biosynthesis genes during petal development. Plant Cell 5:1253-1264.

Mol, J., E. Grotewald, and R. Koes. 1998. How genes paint flowers and seeds. Trends Plant Sci. 3:212-217.

Mudalige, R.G. 2003. Dendrobium flower color: Histology and genetic manipulation. PhD diss., Univ. of Hawaii, Honolulu.

Mudalige, R.G. and A.R. Kuehnle. 2004. Orchid biotechnology in production and improvement. HortScience 39:11-17.

Saito, N., K. Toki, K. Uesato, A. Shigihara, and T. Honda. 1994. An acylated cyaniding glycoside from red-purple flowers of Dendrobium. Phytochemistry 37:245-248.

Seki, H., Y. Nagasugi, Y. Ichinose, T. Shiraishi, and T. Yamada. 1999. Changes in in vivo DNA-protein interactions in pea phenylalanine ammonia-lyase and chalcone synthase gene promoter induced by fungal signal molecules. Plant Cell Physiol. 40:88-95.
Spribille, R. and G. Forkmann. 1981. Genetic control of chalcone synthase activity in flowers of Matthiola incana R. Br. Z. Naturforsch 36c:619-624.

Spribille, R. and G. Forkmann. 1982. Genetic control of chalcone synthase activity in flowers of Antirrhinum majus. Phytochemistry 21:2231-2234.

Tamari, G.,A. Borochov, R.Atzorn, and D. Weiss. 1995. Methyl jasmonate induces pigmentation and flavonoid gene expression in petunia corollas: A possible role in wound response. Physiol. Plant. 94:45-51.

Thompson, J.D., D.G. Higgins, and T.J. Gibson. 1994. CLUSTAL W: Improving the sensitivity of progressive multiple sequence alignment through sequence weighting, position-specific gap penalties and weight matrix choice. Nucleic Acids Res. 22:4673-4680.

Yong, H.H. and N.M. Chua. 1990. Isolation and characterization of genes involved in pigment biosynthesis of orchids, p. 265. In: D.G. Bonham and J. Kornahan (eds.). Proc. of the 13th World Orchid Conf. 1990. 13 ${ }^{\text {th }}$ WOC Proc Trust, Auckland, New Zealand (Abstr.). 